\title{
E-læring 2.0. \\ - Vilkår og muligheder i det sociale web
}

\section{Simon B. Heilesen}

Lektor

Institut for Kommunikation, Virksomhed og

Informationsteknologier, Roskilde Universitet

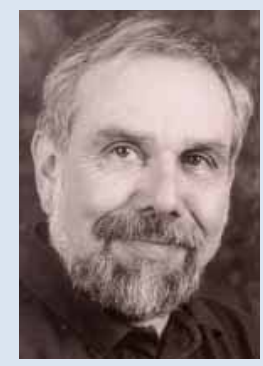

\section{Abstract}

\author{
"The people formerly known as the audience wish to inform \\ media people of our existence, and of a shift in power that goes \\ with the platform shift you've all heard about." \\ (Rosen, 2006)
}

Relationerne mellem afsender og modtager, mellem ekspert og menigmand, er radikalt ændret, og forandringsagenten er Web 2.0, hævder citatet, som egentlig handler om nyhedsmedier. Den myndiggørelse (engelsk: empowerment) af brugeren i konstruktionen af viden, som angiveligt er et resultat af den teknologiske udvikling, er imidlertid generel. Den må derfor også gælde for de anvendelser af Web 2.0, som har at gøre med uddannelse og læring. Det er der følgelig skabt et begreb for, nemlig "e-læring 2.0" (Downes, 2005). Som så mange andre af de nye "versionsbegreber", der er opstået i de seneste år, er også dette skabt i højere grad ud fra en forventning til teknologiens muligheder end ud fra 
veldokumenterede, praktiske resultater, men der synes alligevel at være substans i det. I denne artikel vil vi først klarlægge, hvad begrebet dækker, og dernæst se nærmere på de væsentlige egenskaber, som kendetegner denne nyeste udgave af e-læring, samt give nogle eksempler på elæringsrelevante Web 2.0-applikationer.

Endnu er det sparsomt, hvad der findes af eksempler på større, systematisk tilrettelagte e-læring 2.0-forløb. Men der findes afgrænsede forløb, som kan tjene til at illustrere modtagerens nye, aktive rolle som medproducent af viden i en uformel læringssituation. Lad os indledningsvis se på et eksempel for dermed at gøre begrebet "e-læring 2.0" mere konkret.

I februar 2008 blev der på Stanford Universitetet i Californien afholdt en konference om Metaverse (http://metaverse.stanford.edu/; om begrebet Metaverse, se: Smart, Cascio, \& Paffendorf, 2007). Ved denne lejlighed præsenterede en række inviterede forskere og IT-udviklere deres nyeste resultater for et betalende publikum (Heilesen, 2008). Som en illustration af mulighederne i virtuelle verdener, der er en del af metaverse, blev hele konferencen transmitteret live og gratis i Second Life, hvorfra der også blev stillet spørgsmål direkte til oplægsholderne. Bortset fra denne teknologiske finesse kunne der imidlertid have været tale om den form for hovedsagelig énvejsformidling, vi kender fra kurser og foredragsserier. Men til forskel fra konventionel formidling, kom en del af den konstruktion og deling af viden, som var konferencens formål, til at foregå uden for auditoriet gennem deltagernes aktive brug af en række tjenester på nettet. Konferencenoter blev således opsamlet både i den officielle konference-ki og i deltagernes individuelle weblogs. Billeder fra konferencen blev gjort tilgængelige i Flickr. Videoklip med interviews af deltagerne blev offentliggjort på YouTube, kommentarer til konferencen og forsøget med Second Life blev samlet på konference-webloggen. Og hele denne mængde af observationer og meningstilkendegivelser fra deltagerne blev bundet sammen i et netværk ved hjælp af et enkelt nøgleord (engelsk: tag), metaverseu, som gjorde det muligt at opsamle information på tværs af alle web'ets datatjenester ved hjælp af en søgemaskine eller en social bookmarking applikation.

Deltagerne, de faktiske og de virtuelle, har således på uformel vis samarbejdet om at skabe et "værk" om konferencen og har gennem deres aktive deltagelse i bearbejdelsen af indtrykkene defineret sig som deltagere i et fællesskab. Ved at søge i, sortere og organisere den tilgængelige information kan hver enkelt herefter konstruere sin personlige beretning om begivenheden og trække den information ud, som er relevant for vedkommende. Det er i denne personlige bearbejdning af tilgængelige ressourcer, at Metaverse U konferencen illustrerer nogle væsentlige træk ved e-læring 2.0 og også ved scholarship 2.0. (dvs. nye former for 
forskningssamarbejde og -formidling; et beslægtet emne som dog ikke tages op i nærværende artikel).

\section{Hvorfor e-læring 2.0?}

Der er gået inflation i versioneringer. På nettet startede det med Web 2.0, og siden er der blevet sat versionsnumre på adskillige begreber, herunder, som nævnt, fra den akademiske verden, e-læring, videnskabeligt arbejde og videnskabsformidling.

I software-industrien specificerer et versionsnummer en bestemt udgave af et stykke programmel; og en opgradering med et heltal markerer, at der er tale om en gennemgribende og dermed værdifuld bearbejdning af den tidligere version. Versionering bruges imidlertid også i smart markedsføring af nye udgaver af ældre bøger ("Hypertext 2.0" og "Hypertext 3.0"), opfølgninger på spillefilm ("Die Hard 4.0"), nye bogtitler ("Release 2.0: a design for living in the digital age"), rockalbums (Garbage's "Version 2.0") med mere, hvor det gælder om at signalere noget nyt og måske endda epokegørende.

Umiddelbart knytter der sig derfor nogle lidt tvetydige associationer til et begreb som e-læring 2.0. Bedre bliver det ikke af, at begrebet er blevet lanceret på et tidspunkt, hvor der blandt mange, som beskæftiger sig med feltet, kan konstateres en vis skepsis over for de resultater, der indtil videre er opnået med e-læring: Det er nemlig væsentligt lettere at få øje på dets administrative fordele end på de pædagogiske fortrin (Heilesen \& Jensen, 2006; Underwood \& Tangney, 2008). Samtidig hersker der endnu langt fra enighed om, hvad den brede betegnelse "e-læring" (i den oprindelige "1.0udgave") egentlig dækker over. På grundlag af en nyere dansk undersøgelse af universiteternes e-læringsafdelingers flere forskellige forståelser af begrebet anvendes i den aktuelle sammenhæng den mest generelle definition, som er "alle former for IKT-støttet undervisning" (Dørup, Gomme, Hansen \& Heiberg, 2005).

E-læring 2.0 er mere end blot hype og lappeløsning, som også konferenceeksemplet ovenfor gerne skal vise. Begrebet dækker over nogle forandringer i kommunikationen mellem mennesker, som udbredelsen af internettet har ført med sig, og som er blevet forstærket gennem de seneste års teknologiske udvikling, først og fremmest fremvæksten af det såkaldte Web 2.0.

Web 2.0 blev lanceret ved en konference i oktober 2004, hvor temaet var Web'et som platform (MediaLive International \& O'Reilly Media, 2004). En af konferencens initiativtagere, Tim 0'Reilly (2005), har senere leveret den mest anerkendte definition af Web 2.0 som et forretningskoncept, der kan rumme hele den utrolige rigdom af idéer og nye initiativer, der har ændret World Wide Web fra at være et "opslagsværk" til at blive en platform for 
alle tænkelige former for services og kommunikationsmuligheder mellem brugere. Web 2.0 er siden også blevet en bred betegnelse for programmel, der kan afvikles i en web-browser. Udvalget af sådanne programmer er overvældende, som man kan forvisse sig om ved fx. at kigge på et Web2.0katalog som Go2Web20 (http://www.go2web20.net), og flertallet af programmerne er af typen "social software", det vil sige programmer der understøtter kommunikation og interaktion mellem brugerne.

I sit udgangspunkt er Web 2.0 forbundet med egenskaber som åbenhed, samarbejde, videndeling og social kontakt, og det er netop disse egenskaber, der er af fundamental betydning for forståelsen af e-læring 2.0. Selve termen blev introduceret af den canadiske uddannelsesforsker Stephen Downes (2005) i artiklen "E-learning 2.0", hvor han fremsætter blandt andet disse betragtninger:
What happens when online learning ceases to be like a medium, and becomes more like a platform? What happens when online learning software ceases to be a type of content-consumption tool, where learning is "delivered," and becomes more like a content-authoring tool, where learning is created?

\begin{abstract}
The e-learning application, therefore, begins to look very much like a blogging tool. It represents one node in a web of content, connected to other nodes and content creation services used by other students. It becomes, not an institutional or corporate application, but a personal learning center, where content is reused and remixed according to the student's own needs and interests. It becomes, indeed, not a single application, but a collection of interoperating applications-an environment rather than a system.
\end{abstract}

Downes taler om online-læring, og da fundamentet er Web 2.0, er det klart, at der indgår netbaseret kommunikation i e-læring 2.0. Dermed er "elæring 2.0" et mere snævert begreb end det oprindelige "e-læring". Men der behøver ikke at være tale om rent netbaseret uddannelse. E-læring 2.0 kan lige så godt praktiseres i et samspil mellem tilstedeværelsesundervisning og netbaseret læring, i hvad der bredt betegnes som "blended learning".

Citatet ovenfor indeholder en række nøgleord, hvoraf tre skal fremhæves som værende grundlæggende kendetegn ved e-læring 2.0. På de følgende sider vil e-læring 2.0 blive karakteriseret mere uddybende med udgangspunkt i disse tre kendetegn, som er henholdsvis "personligt læringscenter" (personal learning center), "netværk" (web of content; environment) og "læringsværktøj" (content authoring tool). 


\section{Det personlige læringscenter}

Marc Rosenberg (2007) har i de seneste år gennem foredrag og bøger om e-læring i virksomheder været en markant fortaler for, at der er opstået et nyt paradigme inden for undervisning. Ifølge dette er den lærende i konstant jagt på viden ud fra skiftende behov og underlagt bestandigt skiftende tidsmæssige rammer. Den studerende sidder midt i et spind, hvorfra han eller hun kan trække på bl.a. videnbaser, eksperter, medstuderende i og uden for praksisfællesskaber, e-læringsprogrammer, og naturligvis også undervisere i eller uden for undervisningslokalet. Der er tale om en særdeles individualiseret læreproces, hvor den enkelte har en høj grad af kontrol over både hvordan og hvad han eller hun lærer. Det gamle paradigme, som nu angiveligt visner bort, havde klasseværelset og underviseren som centrum for de studerendes univers; og dette univers var præget af en betydelig ensartethed i mål og midler.

Det billede af netværkende læring med talrige anknytningspunkter, som Rosenberg præsenterer, illustrerer godt forestillingen om det personlige læringscenter, der er centralt i den nye form for e-læring. Blot er Rosenbergs model faktisk ikke særligt ny. En meget lignende model, hvor den lærende er i centrum og trækker på forskellige ressourcer også uden for det fysiske miljø, blev præsenteret en halv snes år tidligere af Oblinger \& Maruyama (1996), dog med de begrænsninger i udvalget af ressourcer, som var gældende i web'ets tidlige år. Disse to forfattere står bestemt heller ikke alene med deres synspunkt. Tanken om at frigøre den studerende fra tid og sted og give ham/hende større kontrol med egen læring er ganske rigt dokumenteret $i$ litteraturen om fjernundervisning og netbaseret læring fra slutningen af 1980'erne op gennem 1990'erne (fx. Keegan, 1986; Kaye, 1989; Harasim, 1989; Harasim et al., 1995; McComb, 1994).

Det egentligt nye er, at det nu rent praktisk kan lade sig gøre, og det med en lethed og i en målestok som kun få havde kunnet forudse for blot nogle år siden. På dette punkt repræsenterer E-læring 2.0 således en evolution snarere end en revolution. Det giver håb om, at man ved hjælp af de nye tekniske og kommunikative muligheder bedre vil være i stand til at afprøve og realisere mange af de gode idéer, der gennem årene har været udviklet om e-læring.

Som allerede antydet aktualiserer skabelsen af det personlige læringscenter spørgsmålet om, hvordan og hvad den lærende så skal lære. Det er nærliggende at antage, at en centralt styret, instruktivistisk pædagogik ikke synes at være den bedst egnede i det nye "læringsparadigme", hvor den lærende i høj grad selv er ansvarlig for tilegnelsen af viden. Paradigmet kommer dermed til at fremstå som noget nyskabende i kulturer, hvor instruktivistisk pædagogik hidtil har været 
fremherskende. De nye teknologiske muligheder forekommer derimod umiddelbart bedre egnet til at understøtte en konstruktivistisk tilgang, hvor den enkelte tager ansvar for egen læring, ligesom teknologien ved at forbedre mulighederne for interaktion mellem brugerne kan facilitere kollaborativ læring. Yderligere forekommer de nye værktøjer, benyttet til konstant at opfylde den lærendes aktuelle behov, at lægge op til en betydelig grad af uformel læring (e.g. Brown, 2002).

I den mest radikale fortolkning kan den uformelle læring have karakter af serendipitous learning dvs. den heldige/tilfældige tilegnelse fra nettet af ny information, som kan omsættes til viden gennem uformel læring(sproces) (e.g. Gritton, 2007). Selv om der for tiden er en tendens til at hylde serendipitet som en nyskabende og spændende Web 2.0-måde at lære på, så er der reelt tale om et velkendt fænomen, der tidligere, sammen med det nært beslægtede "indlejret digression" (dvs. at lade sig lede på tværs af emner ved at følge op på associationer) blev anset for at være alvorlige udfordringer i forbindelse med det at læse hypertekst (Deimann \& Keller, 2006). Masseanvendelsen af World Wide Web som informationskilde har imidlertid i nogen grad gjort disse bekymringer til skamme - brugerne agerer nemlig typisk forholdsvis målrettet i deres arbejde på web'et, og de bliver til stadighed bedre til formulere søgestrategier (Nielsen \& Loranger, 2006). Men naturligvis lærer de nyt også gennem bearbejdningen af den information, de mere eller mindre tilfældigt støder på i deres færden på nettet.

Mere interessant i sammenhæng med uddannelsesverdenen er det, at uformel læring allerede længe har spillet en rolle i uddannelsesforløb, især i dem hvor deltagerne i fællesskab og gennem fælles praksis beskæftiger sig med et domæne. Erfaringerne fra læring i praksisfællesskaber kan uden tvivl udnyttes til at fremme forståelsen og den rationelle udnyttelse af de muligheder, som opstår med realiseringen af det personlige læringscenter.

Men det er vigtigt at holde fast $i$, at adgangen til at deltage $i$ praksisfællesskaber blot udgør en del af potentialet i det personlige læringscenter. Noget nær en hvilken som helst web-applikation kan gøres til et redskab for læring, hvis blot det giver mening for den lærende at benytte den med dette særlige formål. Det kan dreje sig om interaktionsværktøjer, designværktøjer, databaser, med mere. Og det er helt op til den enkelte at kombinere og integrere brugen af dem.

Alt dette til trods vil der i mange sammenhænge stadig være behov for planlagte, formelle undervisningsforløb. Disse kan imidlertid sagtens inddrage Web 2.0 teknologier som åbne læringsressourcer, der sammensættes af underviseren ud fra, hvad der er formålstjenligt i situation. Dette er bl.a. demonstreret af Christian Dalsgaard (2007) i et forslag til en kombination af undervisning og (i hovedsagen) selvstyrede processer med inddragelse af ny teknologi, hvor en kombination af medierings-, refleksions-, konstruktions- og interaktionsredskaber indgår i problemorienterede projektforløb. 


\section{Netværk}

Det personlige læringscenter optræder som en knude i et brugerskabt net af indhold, hævder Downes (2005). Viden konstrueres og distribueres gennem interaktion med dette netværk af applikationer, services, andre brugere og deres læringscentre.

Web 2.0 betegnes også sommetider som "det sociale web", fordi de udvidede muligheder for interaktion mellem nettets brugere er en af de væsentligste egenskaber ved den nye udgave af web'et. Det sociale kan anskues dels ud fra den direkte kontakt mellem mennesker ved hjælp af forskellige former for computermedieret kommunikation, og dels gennem den indirekte sociale kontakt, der opbygges gennem brugergenererede bidrag til den sky af data, eller kollektive intelligens, som ifølge 0'Reilly (2005) er et af kendetegnene ved Web 2.0. Begge former for netmedieret socialt fællesskab er grundlæggende vigtige for e-læring 2.0. Mens Downes (2005) især fokuserer på de ændrede forhold for produktion og transmission af indhold, beskriver John Seely Brown (2002) med termen læringsøkologi måske mere dækkende betydningen af selve interaktionen på nettet, idet en økologi er et åbent, komplekst, adaptivt system, hvis bestanddele er dynamiske og gensidigt afhængige.

Webbets økologiske system er kendetegnet ved et netværk af kontakter mellem individer og grupper og mellem disse og internettets mangfoldige former for tjenester og ressourcer. I læreprocessen opbygger den studerende færdigheder i at tilpasse sig, udnytte og bidrage til dét, som udgør det læringsøkologiske system. At kunne begå sig på Web 2.0 og i elæring 2.0 handler i høj grad om at kunne begå sig socialt i et netværk, dvs. at kunne netværke (på engelsk: networking) eller rettere internetværke (internetworking), fordi der til dels gælder nye vilkår og muligheder for netværksaktiviteterne, når de alene eller primært er netbaserede. For at belyse betingelserne for at konstruere viden i e-læring 2.0 omgivelser kan det derfor være nyttigt at se på de vigtigste kendetegn ved det at internetværke.

I sin artikel om det nye begreb internetworking opregner James Slevin (2004) fem kendetegn ved det at netværke i internet-alderen. Gengivet $i$ meget kort form gælder det for internetworking, at den er:

o Dynamisk, dvs. at den kræver konstant reflekterende ajourføring;

o Ubegrænset i tid og sted. I princippet eksisterer der ikke længere "fremmede";

o Forhandlet, dvs. at aktørernes roller og relationer og de metoder, der tages i brug, ikke som tidligere er funktioner af nærhed, tradition eller slægtskab; 
o Meritokratisk i den forstand, at den enkelte opnår autoritet gennem sin handlen i situationen og ikke som tidligere ud fra forudsigelige relationer;

o Selv-positionerende i den forstand, at synlighed er altafgørende. Med et ofte anvendt slagord handler det om hvem der kender dig, og ikke om hvem du kender.

I det følgende vil vi undersøge disse forskellige kendetegn og give eksempler på, hvordan de afspejles i e-læringssammenhænge.

\section{Dynamisk}

Det gælder for Web 2.0 som også for tidligere computermedieret kommunikation, at den individuelle bruger kun eksisterer i det virtuelle rum i det omfang, han eller hun aktivt tager del i kommunikationen. Netbaseret læring, forstået som andet end blot programmeret undervisning, kræver ligeledes en høj grad af interaktion og en løbende tilpasning til omgivelser og vilkår. Aktiv deltagelse består dels i at man bidrager med tekst, billeder, lyd, video mm., og dels at man er opmærksom både på, hvad andre foretager sig og på, at andre er opmærksomme på, hvad man selv foretager sig. Der foregår således konstant en form for "deltagende overvågning" (Albrechtslund, 2008).

Opmærksomheden på andre består i den mest enkle form i, at man læser og evt. kommenterer andres bidrag på nettet, ganske som man plejer at gøre i de gængse former for computermedieret kommunikation. Men det kan også involvere Web 2.0 teknologier som fx. abonnement på RSS-feeds (automatisk download af information), at man vedligeholder en blogroll (liste over andres weblogs) og måske deltager i en blog cluster (weblogs der henviser til hinanden), eller at man benytter sig af den metainformation, som mange Web 2.0 services er så rige på. Denne kan fx. dreje sig om brugernoter, posting history og fælles tags (nøgleord) i et social bookmarking system som del.icio.us (http://del.icio.us). Eller det kan være henvisninger til andre brugere, der er opmærksomme på det samme emneområde i et bibliografi-system som citeulike (http://www.citeulike.org/).

Opmærksomhed på andres opmærksomhed på en selv har længe været mulig i CMC. I den mest enkle form muliggøres den gennem den historik, som mange e-lærings- og samarbejdssystemer tilbyder og som er ganske vigtig for brugerens oplevelse af at blive "set" i det virtuelle rum. Men også kommentarer til indlæg på diskussionsfora er vidnesbyrd om en sådan opmærksomhed. Web 2.0 byder heller ikke på dette område på egentlige nybrud, men snarere på øgede muligheder for at interagere gennem kommentarer på snart sagt al tænkelig information. Det kan for eksempel være gennem kommentarer til blog-indlæg eller til fotografier i en 
billeddatabase som flickr (http://www.flickr.com/) eller til ratings af og kommentarer til filmklip i videodatabasen YouTube (http://www.youtube.com/).

Et af de store problemer i Web 2.0 er at holde styr på alle de kontaktflader, man nemt udvikler som bruger. Her kan RSS-feeds være en hjælp, fordi de fritager brugeren for opgaven med at lede efter information. Det samme gælder de værktøjer, som tillader, at man indføjer plugins (hjælpeprogrammer), der kan trække på data fra andre services. I skrivende stund har vi kun set den spæde begyndelse til denne form for integration af sociale netværksservices. Men den er godt på vej, for med lanceringen af Google Social API'en i efteråret 2007 er der lagt op til udvikling af platforme for indbyrdes forbundne sociale netværksapplikationer, der gør det muligt for brugeren at vedligeholde hele sit internetværk gennem én sammenhængende brugergrænseflade. Et interessant bud på, hvordan en sådan grænseflade vil kunne tage sig ud, kan man i øvrigt finde i det Google-financierede udviklingsprojekt Socialstream (Clarke, Crowe, Jitkoff, et al., 2006).

\section{Ubegrænset}

Allerede de ældre former for netbaseret læring har gjort op med den binding til tid og sted, som kendetegnede såvel før-elektroniske netværk som konventionel undervisning. Tid og sted mister dog ikke ganske deres betydning som ramme for aktivitet, fordi læringsaktiviteten foregår i en vekselvirkning mellem systemets abstrakte tid og sted og den lærendes oplevelse af situerethed i personlig tid (Jensen \& Heilesen, 2005).

Det nye ved Web 2.0 er nærmere, at grænserne i det virtuelle rum brydes ned. Det virtuelle klasseværelse, sådan som det er udformet i et learning management system (LMS), sætter grænser for tilhørsforhold (institutionen, holdet, gruppen) og for typen af aktiviteter (bestemt gennem en kombination af underviserens valg og systemets funktionsmæssige begrænsninger). Det sociale net, derimod, tilbyder ubegrænset kontakt med alle, der har nogenlunde samme interesser som en selv.

Mange studerende fører således en speciale-blog, hvor de henter råd hos og diskuterer med personer, som ikke nødvendigvis behøver at have tilknytning den formelle uddannelse, som specialeskrivningen indgå som en del af. Et andet eksempel er social bookmarking, hvor et opslag på citeulike eller LibraryThing ikke blot genererer en liste over, hvilken litteratur andre har fundet relevant inden for et bestemt emne. Den gør det også muligt at kigge på, hvad hver enkelt af de øvrige brugere har valgt at bogmærke. Web 2.0-teknologiernes åbenhed, hvor alle kan se alt om alle andre, gør det til en helt naturlig ting at hente gode ideer hos andre, og måske endda at sætte sig i kontakt med dem. 
Ubegrænsetheden underminerer klart nok uddannelsesinstitutionens og underviserens autoritet. Institutionens ressourcer er blot nogle blandt mange, som den studerende kan vælge at trække på. Heri består en del af den uformelle læring, som Web 2.0 hævdes at fremme. Risikoen ved netbaseret uformel læring, forstået som ukontrolleret og usystematisk videnstilegnelse, er således til at få øje på: Den studerende er i høj grad overladt til selv at foretage en sortering og kvalitetsvurdering af de mængder af information, der stilles til rådighed, og den hjælp, der er at hente i fx. andres bogmærkesamlinger, er ofte også usikker, fordi det er svært at gennemskue, hvem der har skabt dem, i hvilken sammenhæng og med hvilket formål.

På den positive side kan fremhæves, at Web 2.0 byder på en række værktøjer, som fremmer videndeling og samarbejde. Det gælder ikke mindst wiki'en, der med projekter som Wikipedia har demonstreret mulighederne i (men også risici ved) fri og grænseløs kooperation. På et mindre ambitiøst og vidtrækkende niveau bruger mange virksomheder, institutioner og studerende med stor effekt værktøjet til at brainstorme, eller at opbygge en fælles fond af viden.

Under det ubegrænsede bør også nævnes begrebet mashup. Mashup bruges dels i betydningen genbrug eller "remix" af produkter, fx. musik eller video, og dels i betydningen kombination af data (Lamb, 2007). Begge dele er relevante for produktion af undervisningsprodukter. Det første som sammenklip og kollager af data, som fx. kan præsenteres i en video på YouTube. Det andet som en filtrering og kombination af data fra internettet. Eksempler på det sidste er Googles My Maps (http://maps.google.com), som gør det let for brugeren at skabe et formidlingsprodukt ved at annotere et landkort eller satellitfoto med tekst, billeder og links; eller Yahoo's Pipes (http://pipes.yahoo.com/pipes/), som tilbyder et værktøj til på forholdsvis enkel vis at konstruere en informationssamling ved at filtrere og sammenstille data af en hvilken som helst type og fra et vilkårligt antal forskellige kilder.

\section{Forhandlet}

I forrige afsnit er nævnt nedbrydningen af institutionel autoritet. Man kan tale om, at lærer- og elevrollerne forhandles i det sociale web. Den studerende har mulighed for selv i højere grad end tidligere at vælge sine "eksperter". Undervisningsorganisationens rolle mindskes, samtidig med at det personlige, selvorganiserende initiativ styrkes. Det har som konsekvens, at det bliver sværere at håndhæve et fælles pensum og mål for opnået læring.

Noget tilsvarende gælder også for undervisningsteknologien. Især tidligere har det været diskuteret om og i hvor høj grad professionelle elæringssystemer (LMS) sætter grænser for, hvordan man kan udforme 
undervisningen. Den nærliggende antagelse har været, at funktionaliteten i et givet system afspejler et underliggende syn på pædagogik, og at et marked domineret af amerikanske produkter således fremmer en international, eller specielt angelsaksisk undervisningskultur (Bang, 2003; Tolsby, Nyvang \& Dirckinck-Holmfeld, 2002). Dette problem synes godt på vej til at løse sig selv med den nye tids sociale software, hvilket kan illustreres med følgende tankevækkende beretning om et undervisningsforløb:

\footnotetext{
"This happened in a program I was recently involved in as a learner. An LMS was the main learning tool (which was a good choice for the program - many of the learners valued the centralized nature of communication and content presentation). After a short period of time, however, groups of learners "broke off" from the program and started holding discussions through Skype, IM, wikis, and other tools. Learners selected tools that were more tightly linked to the types of learning tasks occurring. When the learning was content consumption or simple discussion threads, the LMS was fine. As the learning became more social, learners started using tools with additional functionality. The learning required by the instructors assignments, discussions - still happened in the LMS. But much more meaningful, personal, and relevant learning happened underground - outside of the course."

(Siemens, 2005)
}

I dette tilfælde valgte de studerende selv deres værktøjer. Det er på én gang opløftende, at de studerende er i stand til at gennemskue, hvordan teknologien tjener dem bedst. Samtidig kan det være noget bekymrende, hvis man forestiller sig undervisning som et kontrolleret miljø, hvor medierne bruges i fællesskab til at opnå fælles mål. Dels er der en reel fare for, at fællesskabet i undervisningssituationen svækkes eller går helt $\mathrm{i}$ opløsning, efterhånden som nogle af de studerende på eget initiativ vælger andre platforme at arbejde på. Dels er der en betydelig risiko for, at en del af de studerende, de mindre udfarende og teknologisk mindre ressourcestærke, bliver ladt i stikken, når de stærke studerende går deres egne veje. Og endelig er der en mulighed for, at en del af de studerende kører fagligt af sporet, fordi mulighederne for at kontrollere den enkeltes indsats forringes.

For at imødegå en sådan situation kan det blive nødvendigt enten at se bort fra de e-læringssystemer, der ikke kan følge med tiden, eller også at supplere dem, således at det er underviseren, som stiller en vifte af værktøjer til rådighed, fra hvilke de studerende kan vælge dem, der egner 
sig til deres opgave og arbejdsform (jf. Dalsgaards (2007) tanker om brugen af åbne læringsressourcer).

Videnskonstruktion gennem forhandling kommer også tydeligt til udtryk gennem den tagging, dvs. tilknytning af nøgleord, som gennem de seneste år har fået afgørende betydning for genfinding og kombination af information på web'et på tværs af applikationer og tjenester - som også illustreret med eksemplet fra Metaverse U konferencen. Man taler om folksonomier (folk + taksonomier), fordi enhver bruger frit kan definere egne tags eller vælge eksisterende tags uden hensyn til faglige konventioner (Golder \& Huberman, 2005; Wal, 2005). I praksis samler brugerne sig dog til en vis grad om fælles nøgleord, fordi det gør det lettere både at søge og at blive fundet. Dermed opbygges der en form for konsensus om, hvordan bestemt information skal forstås, kontekstualiseres og klassificeres. De fælles tags er ikke nødvendigvis de samme, som fagfolk inden for informationsbehandling benytter sig af, og begrebshierarkierne kan adskille sig mere eller mindre fra, hvad der konventionelt anses for at være korrekt. Men også denne "skæve brug" på trods af, og sommetider på tværs af, faggrænser kan være med til at skabe en forståelse på brugernes præmisser, og den kan eventuelt være årsag til nye, overraskende indsigter, når uventede sammenstillinger giver mening.

\section{Meritokratisk}

Som nævnt tidligere er brugeren kun til stede i det virtuelle rum i kraft af sin aktive deltagelse. Dertil kommer, at den rolle, brugeren spiller i den konkrete situation, er selvdefineret. Modsat konventionelle netværk, hvor man er bundet af familie- eller arbejdsmæssige relationer samt sociale bånd og normer, skaber man i cyberspace sin egen rolle i en given kontekst. Og rollen kan naturligvis variere på tværs af kontekster. Brugerroller har været diskuteret lige siden sociale fællesskaber begyndte at dukke op på nettet, og personlighedstyper som "nybegynder", "autoritet", "selvhævder", "den troværdige", "den intime", "den selektive" m. fl. er velkendte (se fx. Turkle, 1995; Cutler, 1996). Disse forhold er egentlig ikke ændret med Web 2.0, men de er måske blevet mere væsentlige at være opmærksom på, nu hvor social deltagelse og sociale relationer spiller en stigende rolle.

Specielt er der i forhold til fællesskab i forbindelse med undervisning grund til, at den enkelte lærende forholder sig refleksivt både til sin egen deltagelse og til udvekslingen af information med andre "rolleindehavere". Som altid i netbaseret læring er der for undervisere grund til at overvåge den selvforstærkende tendens til, at de ressourcestærke kommer til at dominere i forhold til de svagere deltagere, som i værste fald ender som passive "vindueskiggere" (lurkers) eller dropper helt ud. 


\section{Selv-positionerende}

I moderne networking er synlighed et succeskriterium i nettets umådelige sociale rum. Hvis man ikke promoverer sig selv og herunder sørger for at synliggøre relationerne til andre, bliver man nærmest ikke-eksisterende, fordi den fysiske verdens traditionelle sociale markører har ringe eller slet ingen effekt i cyberspace. I modsætning til den fysiske verden kan man på nettet definere sin profil forskelligt, alt efter hvilken sammenhæng, man indgår i - professionel/privat, seriøs/legende, osv. En forholdsvis formel og ganske effektfuld profilering opnås ved at bruge en af de mange forskellige former for buddyware eller social networking systemer, som har stor succes i disse år. Som erhvervsaktiv kan man således konstruere sit internetværk og dermed et væsentligt supplement til CV'et, ved hjælp af det forretningsorienterede LinkedIn, mens man som privatperson kan vedligeholde og udbygge personlige kontakter på den sociale legeplads Facebook, mens de unge og musikinteresserede vil kunne definere sig $\mathrm{i}$ forhold til deres kunstneriske præferencer på Myspace. Nyere social networking systemer som fx. Plaxo er særligt interessante ved deres effektive anvendelse af remashing med integrering af billed- og videodatabaser, weblogs, social bookmarking $\mathrm{mm}$. som hjælpemidler til at konstruere en meget personlig netprofil. Endelig bør nævnes virtuelle verdener såsom Second Life, hvor udformningen af avataren, dvs. brugerens skikkelse i den virtuelle verden, er en kompliceret, tidskrævende og måske endda udgiftskrævende proces, som belønnes med anerkendelse og en vis status, når den lykkes godt.

Mere uformel er profileringen i interessegrupper og fællesskaber på nettet. Her definerer den enkelte sig gennem sin indsats i gruppen, som beskrevet ovenfor - det være sig som koordinator, kommentator, researcher, ekspert på et område, eller en af de mange roller, man kan påtage sig i en bestemt situation, som kan omfatte alt lige fra styrkelse af det sociale fællesskab til målrettet kollaborativ videnskonstruktion.

\section{Læringsværktøj}

Med Web 2.0 som platform for et bredt udbud af applikationer og tjenester, af hvilke den enkelte bruger selv kan vælge dem, der passer bedst til et givet formål i en given situation, er der lagt op til et brud med de hidtil dominerende e-læringssystemer (LMS). Downes (2005) ser på baggrund en angelsaksisk undervisningstradition disse primært som formidlingsværktøjer, og der ligger jo også i selve ordet "management" en idé om central styring. De danske erfaringer med e-læring viser imidlertid med al tydelighed, at standard-LMS'er sagtens kan benyttes fx. i problemorienteret projektarbejde og til deltagerstyrede diskussioner (Bang, 2003). Det er anvendelserne af systemerne og ikke softwaren i sig selv, der er interessant i forbindelse med videnskonstruktion. 
Set ud fra en skandinavisk tradition forekommer de nye Web 2.0-værktøjer derfor nok i højere grad faciliterende for kendte, primært kollaborative undervisningsformer end decideret revolutionerende. Men, som det tidligere beskrevne konference-eksempel viser, er rækkevidden af de nye værktøjer til videnskonstruktion noget nær ubegrænset.

Det gælder for det første i forhold til samarbejde. Web 2.0 værktøjer er grænseløse i såvel geografisk som institutionel og faglig forstand. Alle kan finde sammen med alle andre om at udforske og bidrage til et emne, så længe de rent sprogligt kan forstå hinanden. De institutionelle bindinger, repræsenteret blandt andet ved LMS'et som kontrolmekaniske for adgangen til undervisningsmaterialerne, vil i stigende grad blive presset både af Web 2.0 værktøjernes potentiale for uformel læring og af de forskellige OpenCourseware initiativer, som, optimistisk betragtet, lægger op til dannelsen af et globalt "meta-universitet" (Vest, 2006. For et eksempel, se OpenCourseWare Consortium, http://www.ocwconsortium.org). Og nettets uundværlige nøgleord (tags) lægger, som allerede nævnt, op til uformelle kontakter og sommetider uventede indsigter inden for discipliner og på tværs af faggrænser.

Det gælder endvidere i forhold til praktisk anvendelse. Enhver Web 2.0 applikation eller tjeneste kan, som nævnt, bruges som vidensmedium, hvis man vælger at benytte applikationen/tjenesten på den måde. Der behøver endda ikke at herske enighed i en stor brugerskare om at benytte et bestemt programmel, så længe den information, som skabes med systemet, er tilgængelig og søgbar på nettet. Det giver stor frihed for den enkelte til at vælge det eller de værktøjer, som passer til arbejdsstil og formål. Og det giver mulighed for løbende at inddrage nye og stedse mere effektive værktøjer.

Endelig gælder det i forhold til den kreative kombination i form af remix og mashups af information oprindeligt båret af vidt forskellige applikationer (Lamb, 2007). Nye indsigter og nye udtryk kan skabes, individuelt eller kollaborativt ved at sammenstille, integrere, filtrere og præsentere information, som tidligere kun kunne optræde i adskilte medier.

\section{Konklusion}

På de foregående sider har det været forsøgt godtgjort, at e-læring 2.0 reelt byder på nogle nye muligheder og nogle ændrede vilkår for netbaseret og netstøttet læring. "2.0"-versionsnummeret giver mening i den forstand, at der er tale om fornyelse og forbedringer inden for givne rammer. Der er efter alt at dømme tale om en evolution snarere end en revolution, og elæring 2.0 rummer ikke nogen magisk formel for at gøre e-læring til en ubetinget succes. Der er snarere tale om på effektiv vis at virkeliggøre den form for brugerstyret læring i sociale netværk, som længe har været en 
vision blandt mange, som har beskæftiget sig med netbaseret læring. Denne virkeliggørelse synes især at fremme undervisnings- og samarbejdsformer, hvor deltagerne selv gennem deres interaktion bidrager afgørende til at konstruere viden. I en kulturel sammenhæng som den danske, vil web 2.0 teknologierne derfor især blive opfattet som værktøjer til understøtte og videreudvikle nutidige, anerkendte undervisnings- og samarbejdsformer, og udfordringerne vil først og fremmest bestå i at tænke ud over de veletablerede måder at anvende IKT i undervisningen, således at såvel de nye værktøjer som den større frihed for den studerende til at vælge at indgå i formelle og uformelle læringssammenhænge, kan understøttes og styres på en konstruktiv måde. I traditionelt mere instruktivistiske undervisningskulturer er det sandsynligt, at disse nye muligheder i højere grad fremtræder som en udfordring til det bestående, og endda som noget epokegørende, hvad en del af den internationale litteratur om emnet da også vidner om (fx. Brown \& Adler, 2008).

Uanset om e-læring 2.0 opleves som videreudvikling eller nybrud, står det imidlertid klart, at de nye, netværkende, brugerstyrede læringsformer dels udfordrer samtlige konventionelle roller i uddannelsessystemet institutionernes, undervisernes og de studerendes. Dels byder Web 2.0, som er det grænseløse, dynamiske og uophørligt forhandlende sociale net, på delvist ændrede vilkår for sociale kontakter og samarbejde. Og disse nødvendiggør, at såvel lærere som lærende udvikler kompetencer i at internetværke, hvis de skal kunne drage udbytte af e-læring 2.0.

\section{Litteratur}

Albrechtslund, A. (2008). Online Social Networking as Participatory Surveillance. First Monday, 13(3). Rerieved December 4, 2008, from http://www.uic.edu/htbin/cgiwrap/bin/ojs/index.php/fm/article/vie wArticle/2142/1949.

Bang, J. (2003). Findes der en dansk tradition for netbaseret undervisning? Tidsskrift for Universiteternes efter- og videreuddannelse(1). Rerieved March 19, 2008, from http://www.unev.dk/files/jorgen_bang.pdf .

Brown, J. S. (2002). Growing up Digital. How the Web Changes Work, Education, and the Ways People Learn. USDLA Journal, 16(2).

Brown, J. S., \& Adler, R. P. (2008). Minds on Fire: Open Education, the Long Tail, and Learning 2.0. EDUCAUSE Review, 43(1), 16 - 32.

Clarke, M., Crowe, B., Jitkoff, N., Koranda, C., \& Treichler, L. (2006). Socialstream. Retrieved February 12, 2008, from http://hcii.cmu.edu/M-HCI/2006/SocialstreamProject/index.php. 
Cutler, R. H. (1996). Technologies, relations and Selves. In L. Strate, R. L. Jacobson \& S. B. Gibson (Eds.), Communication and Cyberspace. Social Interaction in an Electronic Environment (pp. 317-333). Creskill, NJ: Hampton Press.

Dalsgaard, C. N. (2007). Åbne læringsressourcer - mod en sociokulturel teori om læringsressourcer. Aarhus Universitet, Århus.

Deimann, M., \& Keller, J. M. (2006). Volitional aspects of multimedia learning. Journal of Educational Multimedia and Hypermedia, 15(2), 137-158.

Downes, S. (2005, October 10). E-learning 2.0. eLearn Magazine. Rerieved October 17, 2007, from http://www.elearnmag.org/subpage.cfm?section=articles\&article=29-1.

Dørup, J., Gomme, J., Hansen, A., \& Heiberg, B. (2005). Implementering af elæring ved danske universiteter. Tidsskrift for Universiteternes efter- og videreuddannelse, 6 . Retrieved December 1, 2008, from http://forskningsnettet.dk/da/lom0604.

Golder, S. A., \& Huberman, B. A. (2005). The Structure of Collaborative Tagging Systems. Retrieved December 1, 2008, from http://www.hpl.hp.com/research/idl/papers/tags/tags.pdf.

Gritton, J. (2007). Can serendipitous browsing lead to serendipitous learning? Retrieved February 11, 2008, from http://www.futurelab.org.uk/resources/publications_reports_articles/ web_articles/Web_Article795.

Harasim, L. (1989). On-line Education: A new domain. In R. Mason \& A. Kaye (Eds.), Mindweave. Communication, Computers and Distance Education (pp. 50 - 62). Oxford: Pergamon Press.

Harasim, L., et. al. (1995). Learning networks : field guide to teaching and learning online. Cambridge, Mass.: MIT Press.

Heilesen, S. B. (2008). Metaverse U Conference Notes. In Innovations in Virtual Worlds Working Papers (Vol. 1). Roskilde: Roskilde University. Retrieved May 18, 2008, from http://rudar.ruc.dk/handle/1800/3075.

Heilesen, S. B., \& Jensen, S. S. (2006). Making Sense of Technologically Enhanced Learning in Context: A Research Agenda. In E. Korsgaard Sorensen \& D. Ó Murchú (Eds.), Enhancing Learning Through Technology (pp. 269-291). Hershey; London; Melbourne; Singapore: Information Science Publishing.

Jensen, S. S., \& Heilesen, S. B. (2005). Time, Place and Identity in Project Work on the Net. In T. S. Roberts (Ed.), Computer-Supported Collaborative Learning in Higher Education (pp. 51 - 69). Hershey, London, Melbourne, Singapore: Idea Group. 
Kaye, A. (1989). Computer-mediated communication and distance education. In R. Mason \& A. Kaye (Eds.), Mindweave. Communication, Computers and Distance Education (pp. 3 - 21). Oxford: Pergamon Press.

Keegan, D. (1986). Foundations of distance education. London: Routledge.

Lamb, B. (2007). Dr. Mashup; or, Why Educators Should Learn to Stop Worrying and Love the Remix. EDUCAUSE Review, 42(4), 12-15. Retrieved March 18, 2008, from http://www.educause.edu/apps/er/erm07/erm0740.asp.

MediaLive International, \& O'Reilly Media. (2004). Web 2.0 Conference. Retrieved November 10, 2007, from http://www.web2con.com/web2con/.

McComb, M. (1994). Benefits of computer-mediated communication in college courses. Communication Education, 43(159 - 170).

Nielsen, J., \& Loranger, H. (2006). Prioritizing Web Usability. Berkeley, CA: New Riders.

Oblinger, D. G., \& Maruyama, M. K. (1996). Distributed Learning. Cause Professional Paper Series, 14. . Retrieved February 6, 2008, from http://www.educause.edu/ir/library/pdf/pub3014.pdf.

O'Reilly, T. (2005, 2007). What Is Web 2.0. Design Patterns and Business Models for the Next Generation of Software. Retrieved October 17, 2007, from http://www.oreillynet.com/lpt/a/6228.

Rosen, J. (2006). The People Formerly Known as the Audience. Retrieved March 17, 2008, from http://journalism.nyu.edu/pubzone/weblogs/pressthink/2006/06/27 /ppl_frmr.html.

Rosenberg, M. J. (2007, June 3). Beyond E-learning. New Approaches to Managing and Delivering Organizational Knowledge. Paper presented at the ASTD International Conference, Atlanta. Retrieved February 6, 2008, from http://astd2007.astd.org/PDFs/Handouts\%20for\%20Web/SU201.pdf.

Siemens, G. (2005). When learning goes underground... Retrieved December 1, 2008, from http://connectivism.ca/blog/2005/12/when_learning_goes_undergrou nd.html

Slevin, J. (2004). Internettet og Internetworking (S. B. Heilesen, Trans.). In S. B. Heilesen (Ed.), Det Digitale Nærvær. Viden og design i nye medier (pp. 50-61). Frederiksberg: Samfundslitteratur.

Smart, J., Cascio, J., \& Paffendorf, J. (2007). Metaverse Roadmap. Pathways to the 3D web. San Pedro, CA: Acceleration Studies Foundation.

Retrieved March 1, 2008, from

http://www.metaverseroadmap.org/overview/. 
Tolsby, H., Nyvang, T., \& Dirckinck-Holmfeld, L. (2002, March 26-28). A Survey of Technologies Supporting Virtual Project Based Learning. Paper presented at the Networked learning conference, Sheffield.

Turkle, S. (1995). Life on the screen : identity in the age of the Internet. New York: Simon \& Schuster.

Underwood, J., \& Tangney, B. (2008). CAL'07. Computers \& Education, Volume 50(2), 447 - 448.

Vest, C. M. (2006). Open Content and the Emerging Global Meta-University. EDUCAUSE Review, 41(3), 18 - 30. Retrieved March 18, 2008, from http://connect.educause.edu/Library/EDUCAUSE+Review/OpenConten tandtheEmerging/40626.

Wal, T. V. (2005, Februar 21, 2005). Explaining and Showing Broad and Narrow Folksonomies. Retrieved november 13, 2007, from http://www.personalinfocloud.com/2005/02/explaining_and_.html 